\title{
Synthesis and electrical properties of $\mathrm{Ln}_{2} \mathrm{CuO}_{4+\delta}$ (Ln: Nd or La) mixed conductor sputter deposited coatings
}

\author{
P. Briois • J. C. Oliveira $\cdot$ F. Lapostolle $\cdot$ F. Perry • \\ A. Billard • A. Cavaleiro
}

Received: 6 September 2007 / Revised: 6 December 2007 / Accepted: 18 December 2007 / Published online: 14 January 2008

(C) Springer-Verlag 2007

\begin{abstract}
Nd}_{2} \mathrm{CuO}_{4}$ and $\mathrm{La}_{2} \mathrm{CuO}_{4}$ are potential candidates as cathode material for intermediate temperature-solid oxide fuel cells. $\mathrm{Nd}-\mathrm{Cu}$ and $\mathrm{La}-\mathrm{Cu}$ oxides were cosputtered on rotating substrates from metallic $\mathrm{La}, \mathrm{Nd}$ and $\mathrm{Cu}$ targets in the presence of a reactive argon-oxygen gas mixture. Structural and chemical features of these films have been determined by X-ray diffraction and energydispersive spectroscopy. Their electrical resistivity was measured using the four-point probe method. As-deposited $\mathrm{Nd}-\mathrm{Cu}$ based coatings are amorphous and, after annealing, crystallise in $\mathrm{K}_{2} \mathrm{NiF}_{4+\delta}$-type structure for $\mathrm{Nd} / \mathrm{Cu}$ atomic ratio of 2 , with more or less $\mathrm{Nd}_{2} \mathrm{O}_{3}$ or $\mathrm{CuO}$, depending on whether $\mathrm{Nd}$ or $\mathrm{Cu}$ is in excess, respectively. As-deposited $\mathrm{La}-\mathrm{Cu}$ based coatings are also amorphous and crystallise in $\mathrm{La}_{2} \mathrm{CuO}_{4}$ for $\mathrm{La} / \mathrm{Cu}>2$ or in $\mathrm{LaCuO}_{3 \pm \delta}$ perovskite-type structure when $\mathrm{Cu}$ is in excess. The electrical measurements show a clear relation between resistivity and structure of the coatings. After annealing, crystallised neodymium-based
\end{abstract}

Paper presented at the 11th EuroConference on the Science and Technology of Ionics, Batz-sur-Mer, Sept. 9-15, 2007.

\author{
P. Briois $\cdot$ F. Lapostolle $(\triangle) \cdot$ A. Billard \\ LERMPS-UTBM, Site de Montbéliard, \\ 90010 Belfort cedex, France \\ e-mail: frederic.lapostolle@utbm.fr \\ J. C. Oliveira $\cdot$ A. Cavaleiro \\ ICEMS, Mechanical Department, University of Coimbra, \\ Rue Luis Reis Santos, \\ 3030-788 Coimbra, Portugal \\ F. Perry \\ PVDco s.à.r.l., \\ Rue du Haut Buisson, \\ 54120 Baccarat, France
}

coatings show higher resistivity than lanthanum-based ones. Finally, $\mathrm{LaCuO}_{3 \pm \delta}$ exhibit higher resistivity than $\mathrm{La}_{2} \mathrm{CuO}_{4}$.

Keywords Magnetron sputtering $\cdot \mathrm{La}_{2} \mathrm{CuO}_{4} \cdot \mathrm{LaCuO}_{3}$. $\mathrm{Nd}_{2} \mathrm{CuO}_{4} \cdot$ Cathode material $\cdot$ IT-SOFC

\section{Introduction}

Reducing the operating temperature of solid oxide fuel cells (SOFC) down to about $900-1,000 \mathrm{~K}$ without a significant decrease in the power leads to two main problems. The first one is the low ionic conductivity of electrolytes and the second is the high polarisation resistance of the cathode. One solution to overcome these drawbacks remains to be a reduction in the electrolyte thickness to decrease its ohmic drop at low temperatures. Concerning the cathode material, using a mixed ionic and electronic conducting material appears to be a promising way to lower the cathode polarisation.

Up to now, most of the studies concerned with cathode materials for SOFC are devoted to perovskite-type oxides. Recently, a new family of oxides of general formulation $\mathrm{A}_{2} \mathrm{MO}_{4+y}$ not only as a cathode material for SOFC applications but also as catalysts, sensors and superconductors [4-9], synthesised by different techniques like pulsed laser deposition, molecular beam epitaxy or sputtering [10-15], was first investigated by Mauvy et al. [1] and later by other authors [2-3].

In this paper, we investigate the feasibility of $\mathrm{Nd}_{2} \mathrm{CuO}_{4+\delta}$ or $\mathrm{La}_{2} \mathrm{CuO}_{4+\delta}$ coatings obtained by hybrid device reactive magnetron sputtering as potential cathode material for intermediate temperature (IT) SOFC. Indeed, reactive magnetron sputtering is a powerful technique for deposition 